ORIGINAL ARTICLE / ARTIGO ORIGINAL

The impact of the investigation on deaths classified as garbage codes on the quality of the cause-of-death information in the Northeast region, Brazil

\title{
Avaliação do impacto da investigação dos óbitos com códigos garbage na qualidade da informação sobre causas de morte no nordeste do Brasil
}

\author{
Conceição Maria de Oliveira' (1), Denise Leão Ciríaco"l (1), Cristiana Ferreira da Silva"l! (1), \\ Herbert Charles Silva Barros" (1), Carolina Cândida da Cunhalv (D), Elisabeth Barboza Françav
}

\begin{abstract}
Objective: to evaluate the impact of investigation of deaths classified as garbage codes (GC) on the quality of the causes-of-death information in municipalities in the Northeast region of Brazil in 2017. Method: an investigation was conducted on the deaths classified as GC in 18 municipalities in the Northeast region as follows: identification of deaths with priority GC; review of medical records from health services and forensic institutes; and evaluation of the reclassification of causes of death according to the International Classification of Diseases (ICD-10) and groupings of the Global Burden of Disease 2015 (GBD 2015). Results: among 18,681 deaths classified as priority GC, 7,352 (39\%) were investigated and, of these, 5,160 (70\%) had reclassified causes, of which 4,087 (79\%) were changed to specified causes. Ill-defined causes $(n=4,392)$ were the most frequent among GC and those with a higher proportion of cause change (80\%), and $57 \%$ were changed to specified causes. The reduction of GC contributed to the detection of a wide variety of specific causes according to groups of level 3 of the GBD 2015, being the interpersonal violence the cause that obtained the highest percentage change (11.8\%). Conclusion: The investigation of deaths with priority GC proved to be an important strategy to specify causes of death, and it may influence the formulation, execution and evaluation of health policies.

Keywords: Mortality. Causes of death. Health evaluation. Data accuracy.
\end{abstract}

'Executive Board of Health Surveillance, Health Secretariat of Recife - Recife (PE), Brazil.

"Information Management and Health Situation Analysis, Superintendence of Health Surveillance, Health Secretariat of Alagoas Maceió (AL), Brazil.

"'Nucleus of Epidemiology, Secretariat for Hospital Administration of Maracanaú - Maracanaú (CE), Brazil.

"vesearch Group on Epidemiology and Health Evaluation, Federal University of Minas Gerais - Belo Horizonte (MG), Brazil.

vGraduate in Public Health, Federal University of Minas Gerais - Belo Horizonte (MG), Brazil.

Corresponding author: Conceição Maria de Oliveira. Avenida Visconde de Suassuna, 658, Santo Amaro, CEP: 50050-540, Recife, PE, Brazil. E-mail: coliveira@recife.pe.gov.br

Conflict of Interests: Nothing to declare - Financial Support: Vital Strategies as part of the Bloomberg Philanthropies Data for Health Initiative (Project 23998 Fundep/UFMG). 
RESUMO: Objetivo: avaliar o impacto da investigação dos óbitos classificados como causas garbage (CG) na qualidade da informação sobre causas de morte em municípios da região Nordeste do Brasil em 2017. Método: estudo avaliativo sobre a investigação dos óbitos com CG em 18 municípios do Nordeste, a partir do seguinte fluxo: identificação de óbitos com CG prioritárias; investigação em prontuários e nos laudos dos institutos de medicina legal; e avaliação da requalificação e especificação das causas de morte de acordo com a Código Internacional de Doenças e segundo grupos de causas do estudo Global Burden of Disease 2015 (GBD 2015). Resultados: dentre 18.681 óbitos classificados como CG prioritárias, 7.352 (39\%) foram investigados e, destes, $5.160(70 \%)$ tiveram causas reclassificadas, das quais $4.087(79 \%)$ para causas especificadas. As causas mal definidas $(\mathrm{n}=4.392)$ foram as mais frequentes dentre as CG e as que apresentaram maior proporção de mudança de causa (80\%), e 57\% alteraram para causas especificadas. A redução das CG contribuiu para detecção de grande variedade de causas específicas segundo grupos do nível 3 do GBD 2015, sendo a violência interpessoal a que obteve maior mudança percentual (11,8\%). Conclusão: a investigação dos óbitos com CG prioritárias revelou-se importante estratégia para especificação das causas básicas de morte, podendo influenciar diretamente na formulação, execução e avaliação das políticas de saúde.

Palavras-chave: Mortalidade. Causas de morte. Avaliação em saúde. Acurácia dos dados.

\section{INTRODUCTION}

The Mortality Information System (SIM), implemented in 1975 in Brazil, aims to outline the mortality profile, including the evaluation of the underlying cause of death, enabling thus the analysis of information according to descriptive variables related to the space, time and characteristics of individuals and populations. However, to reflect reality and subsidize the planning of strategic actions to minimize avoidable outcomes, good quality of information must be available in this system ${ }^{1}$. An improvement of the SIM information regarding coverage, regularity and proportion of ill-defined causes is perceived; however, the latter dimension is still at lower levels than those achieved by the two other indicators ${ }^{2,3}$.

Ill-defined causes, belonging to Chapter XVIII of the International Statistical Classification of Diseases and Related Health Problems, 10th version (ICD-10), represent a gap in knowledge about the causes of death ${ }^{4}$. They refer to cases without medical assistance and to those in which there was assistance, but it was not possible to determine the underlying cause of death or the physician declared only one symptom or sign ${ }^{2,3,5-7}$.

From this perspective, since 2006 the Ministry of Health (MH) has incorporated the investigation of ill-defined causes as routine of epidemiological surveillance ${ }^{2,5-8}$. As a probable result of the national effort to clarify the question, in 2016 Brazil showed a proportion of $5.8 \%$ of ill-defined causes, the North $(7.8 \%)$ and Northeast $(7.2 \%)$ regions being responsible for the greater accumulation of deaths caused by these causes. It is noteworthy that the Northeast concentrates one third of the deaths due to ill-defined causes of 
the country ${ }^{9}$, and the states of the region present a coverage of the SIM varying from $81 \%$ to $98 \%{ }^{10}$.

Combining the positive outcomes of the investigation of ill-defined causes of death, $\mathrm{MH}$ expanded the investigation to other causes considered garbage, in order to contribute to the planning of actions in the collective scope $\mathrm{e}^{11-13}$. The diagnoses classified in the death certificates (DC) as garbage are ill-defined or nonspecific codes, therefore inappropriate from the viewpoint of public health ${ }^{1,11}$, because they make it impossible for health services to recognize the real problems and/or diseases that caused the death chain, hindering the definition of priority strategies aimed at reducing harm. Thus, there is an international agenda aimed at improving information on mortality, whose milestone refers to the Global Burden of Disease study published in $1996^{1,11}$.

International and national studies have indicated the importance of advancing in the discussion of information quality of garbage code deaths ${ }^{1,11-13}$. Considering the relevance of the investigations of these deaths and their influence on the formulation, implementation and evaluation of health intervention policies, the aim of this study is to evaluate the impact of the investigation of deaths classified as garbage on the quality of information on causes of death in municipalities in Northeastern Brazil in 2017.

\section{METHODS}

This is an evaluative study on the investigation of deaths classified as garbage codes, carried out in 18 municipalities in the Northeastern region of Brazil, 4 from the state of Ceará (Caucaia, Fortaleza, Maracanaú and Sobral), 1 from Rio Grande do Norte (Natal), 1 from Paraíba (João Pessoa), 3 from Pernambuco (Caruaru, Jaboatão dos Guararapes and Recife), 2 from Alagoas (Arapiraca and Maceió), 3 from Sergipe (Aracaju, Itabaiana and Lagarto), and 4 from Bahia (Feira de Santana, Itabuna, Salvador and Vitória da Conquista).

The deaths of residents in these municipalities correspond to $25 \%$ of the total death record of the Northeast region". The selection of municipalities was defined by the higher proportion of deaths with garbage coding and/or adherence to the $\mathrm{MH}$ research project of these deaths ${ }^{14}$.

At the base of the local SIM, the teams of the municipalities initially identified deaths in the age group from 1 to 90 years old with priority garbage coding of residents in their territory in 2017. The garbage coding considered priority by the $\mathrm{MH}$ were: septicemia (ICD codes-10 A40 to A41), unspecified neoplasia (C26, C55, C76, C78, C79 and C80), essential hypertension (I10), pulmonary embolism (I26), cardiac insufficiency and unspecified heart diseases (I50 and I 51.1), unspecified stroke and sequelae of stroke (I62.1, I62.9, I64, I67.4, I67.9, I69.4 and I69.8), pneumonia (J15.9 and J18), respiratory insufficiency and other respiratory disorders (J96 and J98), renal insufficiency (N17 and N19), ill-defined causes (R00-R99, except R95), unspecified transport accidents, unspecified homicides (V87.0, V87.1, V87.4 to 
V87.9, V89 and V99), and external causes with undetermined intent and unspecified accidents (Y10 to Y34 and X59). It is noteworthy that the specified 3-character codes include those of 4 characters of the category.

Garbage code deaths were investigated by the epidemiological surveillance teams of the municipalities, either alone or with state teams and/ or hospitals where the deaths occurred. Most professionals already performed the investigation of deaths with ill-defined causes. Thus, the trainings, when performed, were through meetings pointing to the importance of specifying garbage code deaths, with presentation of the protocol and the investigation form of the $\mathrm{MH}$.

The investigation of the cases was made by consulting the medical records of the establishments in which the event occurred, following the hospital research manual proposed by the $\mathrm{MH}^{14}$. For data collection in hospitals, we used a standard form of investigation of garbage code deaths called IOCMD-H, provided by the MH. It is noteworthy that the deaths due to external causes were also investigated in the Institutes of Legal Medicine (IML) by the teams of the municipality that is home to this service. The deaths investigated underwent a process of requalification of causes of death, with alteration of causes in the municipal SIM and filling the fields "death investigated," "date of investigation," and "source of investigation."

To evaluate the impact of these investigations, the national SIM database of the 18 municipalities was used, provided by the $\mathrm{MH}$ in April 2019. The following variables were analyzed: death investigated, municipality of residence, original underlying cause and underlying cause after investigation. The causes of death after investigation were coded according to ICD-10, being grouped into specific causes according to groups of levels 3 and 4 of the Global Burden of Disease Study $2015^{11}$.

The deaths investigated were considered to be requalified when there was a change in the underlying cause, even if to another garbage code. The causes were classified as specified when they changed to non-garbage codes. Data were analyzed in the programs Tabwin and Epi Info version 7.2.2.6, through descriptive statistics (absolute and relative frequencies).

This study was approved by the Ethics and Research Committee of the Federal University of Minas Gerais (CAEE 75555317.0.0000.5149) and developed according to the Ethical precepts established in ordinance $466 / 12$ of the National Health Council.

\section{RESULTS}

In the 18 municipalities studied in the Northeast region, 18,681 deaths with priority garbage codes were identified, being 7,352 (39\%) investigated and, of these, 5,160 (70\%) had the causes reclassified, of which 4,087 (79\%) were changed to specified causes (Figure 1). 

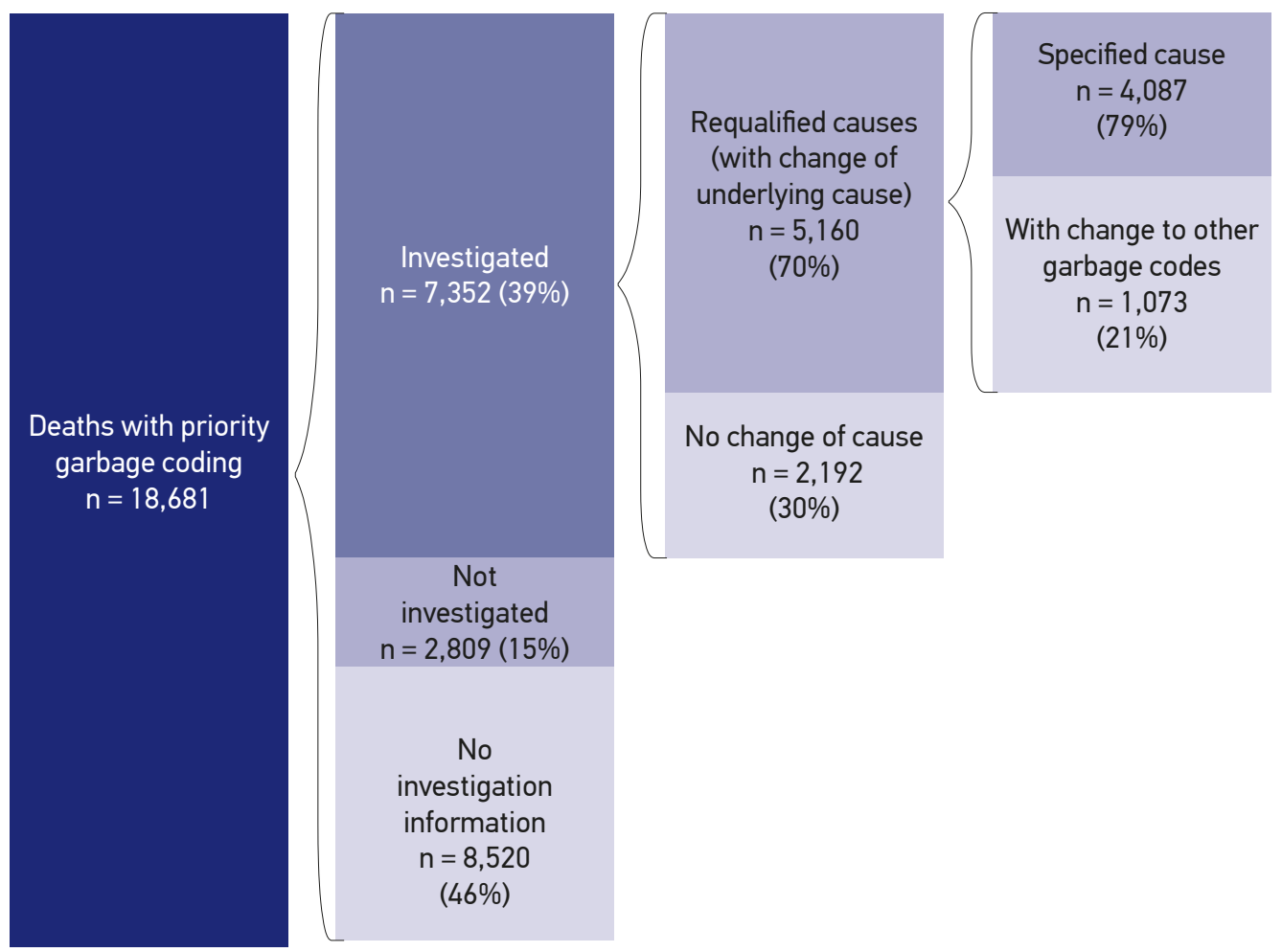

Figure 1. Deaths with priority garbage codes and research status. Northeast region, Brazil, 2017.

Deaths with priority garbage codes corresponded to $23.5 \%$ of the total deaths in the municipalities studied. However, 6 municipalities had more than $30 \%$ of garbage code deaths, especially Arapiraca-AL and Feira de Santana-BA with $41.3 \%$ and $40.2 \%$, respectively. The proportion of deaths with priority garbage codes investigated ranged from $8 \%$ to $80 \%$, being Feira de Santana-BA the municipality of the lower extremity and Lagarto-SE, the upper extremity. It is noteworthy that Sobral-CE, Natal-RN, Caruaru-PE, Maceió-AL and Itabuna-BA specified the causes of death above $80 \%$ among the requalified causes, and no difference was observed regarding the typification of the municipality, whether capital or countryside (Table 1 ).

Among the garbage codes in the original DC, the ill-defined ones $(n=4,392)$ and the pneumonia $(\mathrm{n}=3,322)$ were highlighted. The external causes stood out with $66.7 \%$ of the deaths with indeterminate intent and unspecified accident investigated. Essential hypertension, unspecified stroke and heart failure and other unspecified heart diseases obtained a research proportion of less than $30 \%$. It is noteworthy that although ill-defined deaths present the highest proportion of change of cause after investigation (80.2\%), only $57.4 \%$ of these deaths had their causes specified (Graph 1). 
Table 1. Total deaths with priority garbage codes and research results per municipality. Northeast region, Brazil, 2017.

\begin{tabular}{|c|c|c|c|c|c|}
\hline Municipality-FU & $\begin{array}{l}\text { Total } \\
\text { deaths }\end{array}$ & $\begin{array}{c}\text { Priority garbage } \\
\text { codes }\end{array}$ & Investigated & $\begin{array}{l}\text { Requalified } \\
\text { cause }\end{array}$ & $\begin{array}{l}\text { Specified } \\
\text { cause }\end{array}$ \\
\hline & No. & No. (\%) & No. (\%) & No. (\%) & No. (\%) \\
\hline Caucaia-CE & 1,294 & $320(24.7)$ & $94(29.4)$ & $45(47.9)$ & 31 (68.9) \\
\hline Fortaleza-CE & 17,031 & $3,556(20.9)$ & $974(27.4)$ & $522(53.6)$ & 398 (76.2) \\
\hline Maracanaú-CE & 1,036 & $226(21.8)$ & $124(54.9)$ & $64(51.6)$ & $36(56.3)$ \\
\hline Sobral-CE & 1,243 & $444(35.7)$ & $330(74.3)$ & $315(95.5)$ & $261(82.9)$ \\
\hline Natal-RN & 5,258 & $875(16.6)$ & $276(31.5)$ & $253(91.7)$ & $247(97.6)$ \\
\hline João Pessoa-PB & 4,864 & $823(16.9)$ & $227(27.6)$ & $161(70.9)$ & $123(76.4)$ \\
\hline Caruaru-PE & 1,921 & $424(22.1)$ & $202(47.6)$ & $172(85.1)$ & $148(86.0)$ \\
\hline $\begin{array}{l}\text { Jaboatão dos } \\
\text { Guararapes-PE }\end{array}$ & 1,648 & $326(19.8)$ & 80 in (24.5) & $44(55.0)$ & $27(61.4)$ \\
\hline Recife-PE & 10,471 & 2,009 (19.2) & 987 (49.1) & 621 (62.9) & $496(79.9)$ \\
\hline Arapiraca-AL & 1,470 & $607(41.3)$ & 315 (51.9) & $128(40.6)$ & 89 (69.5) \\
\hline Maceió-AL & 6,134 & $1,209(19.7)$ & $493(40.8)$ & $372(75.5)$ & 346 (93.0) \\
\hline Aracaju-SE & 3,326 & $675(20.3)$ & $522(77.3)$ & $305(58.4)$ & $216(70.8)$ \\
\hline Itabaiana-SE & 459 & $179(39.0)$ & $141(78.8)$ & 99 (70.2) & 73 (73.7) \\
\hline Lagarto-SE & 471 & $134(28.5)$ & $106(79.1)$ & $54(50.9)$ & $30(55.6)$ \\
\hline $\begin{array}{c}\text { Feira de } \\
\text { Santana-BA }\end{array}$ & 3,586 & $1,443(40.2)$ & $110(7.6)$ & 38 (34.5) & $25(65.8)$ \\
\hline Itabuna-BA & 1,527 & $477(31.2)$ & $172(36.1)$ & $104(60.5)$ & $85(81.7)$ \\
\hline Salvador-BA & 15,728 & $4,244(27.0)$ & $2,028(47.8)$ & $1,731(85.4)$ & 1,382 (79.8) \\
\hline $\begin{array}{c}\text { Vitória da } \\
\text { Conquista-BA }\end{array}$ & 2,163 & $710(32.8)$ & $171(24.1)$ & $132(77.2)$ & $74(56.1)$ \\
\hline Total & 79,630 & 18,681 (23.5) & 7,352 (39.4) & $5,160(70.2)$ & 4,087 (79.2) \\
\hline
\end{tabular}

Note: All percentages were calculated in relation to the previous column.

Among the deaths with priority garbage codes investigated, transport accidents and homicides were the ones that presented the highest reduction $(-78 \%)$. Deaths from pulmonary embolism, stroke, essential hypertension, and cardiac insufficiency and heart diseases obtained a specification of the cause below $50 \%$. The reduction in the garbage codes contributed to the detection of a wide variety of underlying causes, which were classified according to the level 3 groups of the GBD 2015 study, and the interpersonal violence reached the greatest variation percentage after investigation (11.8\%) (Graph 2). 


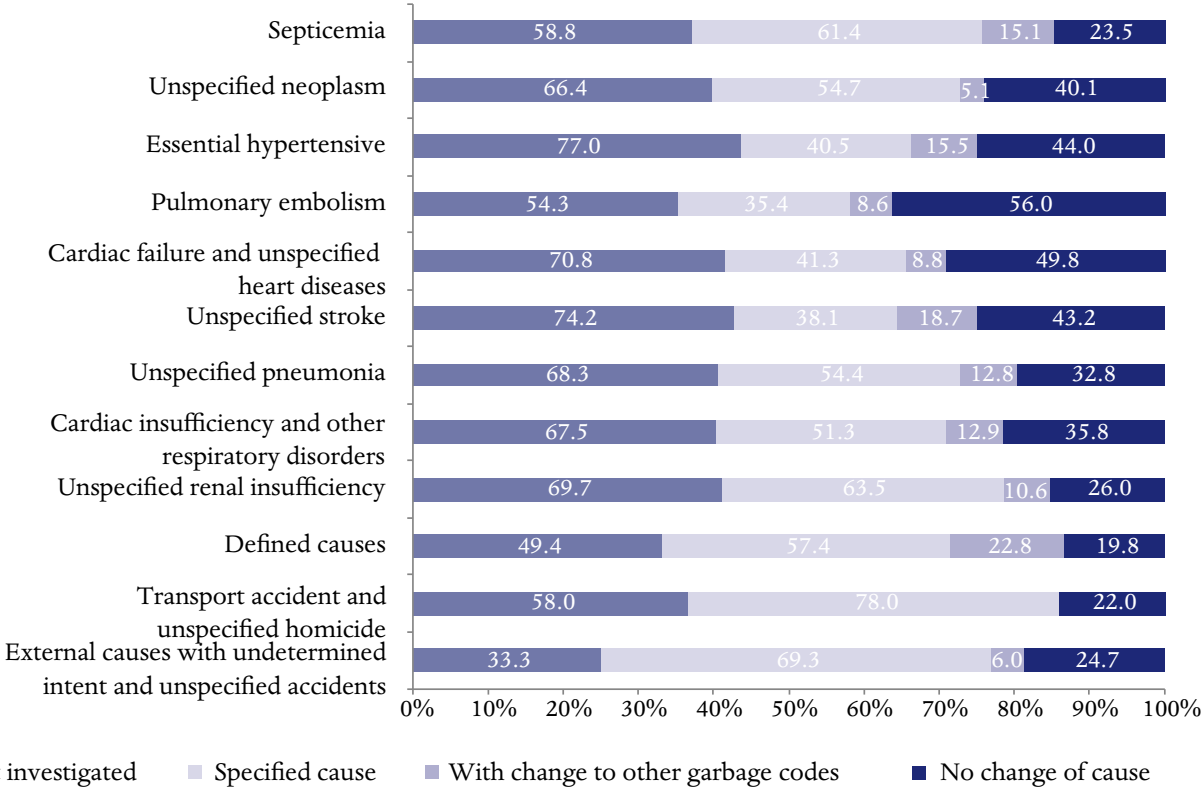

Not investigated $\quad$ Specified cause

With change to other garbage codes

No change of cause

Graph 1. Priority garbage codes group and research status. Northeast region, Brazil, 2017.

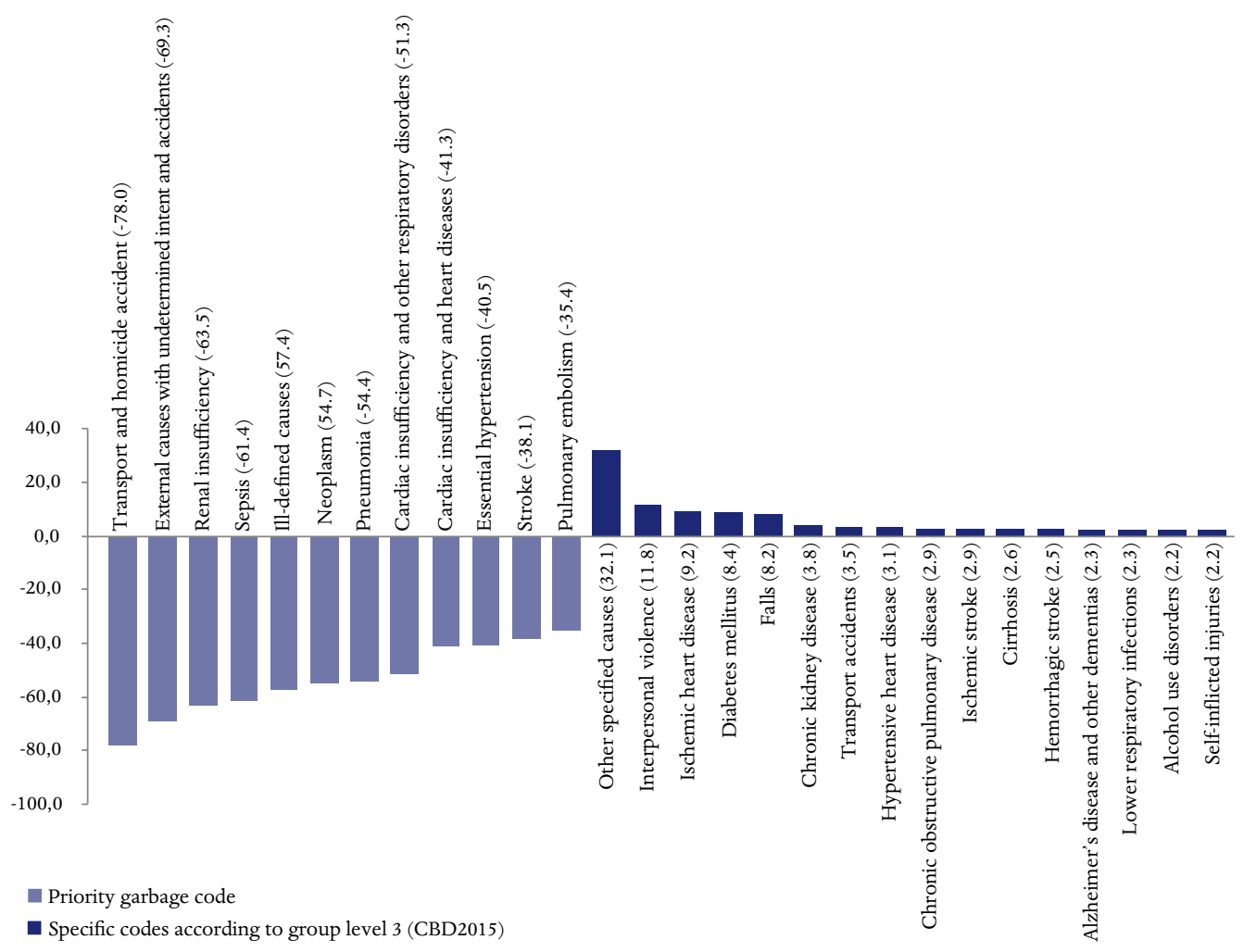

Graph 2. Proportional variation between priority garbage codes and specified causes after investigation. Northeast region, Brazil, 2017. 


\section{DISCUSSION}

In the municipalities studied in the Northeast region of Brazil, about one quarter of the deaths were classified as priority garbage codes. The incorrect record and the low quality of causes of death can pose major challenges for the production of accurate estimates, directly interfering in the planning of actions to minimize avoidable outcomes ${ }^{1,13}$.

Deaths with garbage coding still have little attention from professionals and health services; however, studies indicate the need to develop strategies aimed at advancing the specification of these causes ${ }^{11,15}$. The investigation of these deaths aims to improve the quality of SIM and contribute to the understanding of the changes in mortality patterns and the impact they can produce in different groups of the population ${ }^{14}$. Also, it indicates to the health services the main problems related to the completion of causes of death in the DC, enabling the implementation of public policies and actions aimed at reducing morbidity and mortality ${ }^{1}$.

Of the investigated deaths evaluated in this study, more than half had their causes specified, confirming thus the importance of this strategy to qualify the causes of death. An investigation on deaths due to ill-defined causes in Brazil found that the study enabled the reclassification of the underlying cause between $50 \%$ and $80 \%$ in the states of the coun$\operatorname{try}^{16}$. These findings showed that the garbage codes marked on the DC could be avoided for many deaths, if the physicians sought complementary information in the medical records ${ }^{16,17}$. Thus, it is important to raise the awareness of the physician about the correct completion of the instrument, so that these professionals can specify in the DC the conditions and causes that led to death ${ }^{18}$.

In this study, we expected to find a lower percentage of deaths with garbage coding and a better specification of these causes in the capitals. However, this was not observed, which is worrying, because the capitals presumably have better access to diagnosis and quality of care, in addition to better information on causes of death with consequent reduction in the garbage codes ${ }^{16}$. The SIM coverage and the quality of information on causes of death vary widely according to the region. We believe that, as the mortality coverage is improved, the percentage of nonspecific causes decreases ${ }^{2}$.

Among the garbage codes registered before the investigation, the ill-defined causes and the pneumonias were highlighted, results similar to those found in a research conducted in Belo Horizonte ${ }^{1}$. Brazil has excelled in reducing the proportion of deaths due to ill-defined causes; however, there is a higher number of deaths due to unspecific causes of chapters of ICD-10 than in chapter XVIII ${ }^{14}$. The international scenario corroborates the increase in the relevance of garbage coding according to the GBD studies, which associate higher proportions in countries with economic activity restricted to primary production and health systems with low case management ${ }^{11,13}$.

External causes with indeterminate intent and unspecified accidents, as well as transport accidents and unspecified homicides, were the most investigated deaths, being more than half reclassified as specified causes. These deaths may have several sources of investigation, such as consultation with hospital records, autopsy reports, police reports, press releases, and the 
integration of the SIM database with the traffic accident database with victims. The consultation of these sources may lead to a specific diagnosis of the cause of death ${ }^{1,16,19}$. It is noteworthy that the high reduction in transport accidents and unspecified homicides $(-78 \%)$ and external causes with indeterminate intent and unspecified accidents $(-69.3 \%)$ may have had greater weight in the countryside, due to the phenomenon of interiorization of violence, especially in the Northeast, and the increase in the fleet of vehicles, mainly motorcycles ${ }^{20,21}$.

Less than $30 \%$ of deaths by essential hypertension, unspecified stroke and cardiac insufficiency, and other unspecified heart diseases were investigated. The difficulty in specifying these causes may be associated with the occurrence of these deaths in less than 24 hours of patient admission to the health establishment, without the issuance of medical records and with refusal of the family to refer the body to the Death Notification Service.

The reduction in garbage coding contributed to the specification of a wide variety of causes according to groups of levels 3 and 4 of the GBD 2015 study. It is noteworthy that, since 1990, international efforts aimed at understanding the GBD were undertaken and global measures for 187 countries were already possible with the GBD 2010 study, published in 2012, which sought to offer a response to the health of populations, encouraging debates on health poli$\mathrm{cies}^{22}$. In this context, Brazil has obtained pioneering and broad estimates of levels and tendencies of disability and death through the GBD 2015 and 2016 studies, boosting the concreteness of this project in the country and guiding it to the discussion of the quality of the completion of the DC not only for the codes R00-R99, but also for the garbage codes ${ }^{11-13}$.

The limitations of this research are related to the differences between researchers and the quality of data records in the various municipalities studied. In addition, attention should be paid not to extrapolate the results, since we did not use a method capable of evaluating the impact of investigations over time and controlling other variables that may have influenced the results. The death investigation process performed by this group of causes was recently implemented in some municipalities of Brazil. Thus, to evaluate the impact of this strategy in order to identify the weaknesses and potentialities was necessary, contributing thus to the improvement of investigations and a possible implementation in the other municipalities of the country.

\section{CONCLUSION}

The investigation of deaths with priority GC proved to be an important strategy to specify causes of death, and it may influence the formulation, execution and evaluation of health policies. Epidemiological surveillance services of the municipalities and states must continue working with unspecified external causes and those with undetermined intent. However, the current volume of DC issued with garbage coding prevents this investigation by the epidemiological surveillance for the other causes, and it reinforces the importance of qualified professionals who fill out the DC, which would reduce the number of garbage code deaths recorded in SIM. 


\section{REFERENCES}

1. Ishitani LH, Teixeira RA, Abreu DMX, Paixão LMMM, França EB. Quality of mortality statistics' information: garbage codes as causes of death in Belo Horizonte, 2011-2013. Rev Bras Epidemiol. 2017;20(supl 1):34-45. http: / / dx.doi.org/10.1590/1980-5497201700050004

2. Lima EEC, Queiroz BL. Evolution of the deaths registry system in Brazil: associations with changes in the mortality profile, under-registration of death counts, and ill-defined causes of death. Cad Saúde Pública. 2014;30(8):1721-30. http:/ / dx.doi.org/ 10.1590/0102-311X00131113

3. Frias PG, Pereira PMH, Andrade CLT, Lira PIC, Szwarcwald CL. Avaliação da adequação das informações de mortalidade e nascidos vivos no estado de Pernambuco, Brasil. Cad Saúde Pública. 2010;26(4):671-81. http:// dx.doi.org/10.1590/ S0102-311X2010000400010

4. Mello Jorge MHP, Laurenti R, Gotlieb SLD. Análise da qualidade das estatísticas vitais brasileiras: a experiência de implantação do SIM e do SINASC. Ciênc Saúde Coletiva. 2007;12(3):643-54. http:/ / dx.doi.org/ 10.1590/S1413-81232007000300014

5. Cunha CC, Vasconcelos AMN, Souza MFM, França E. Assessment of the investigation of deaths from ill-defined causes in the state of Bahia in 2010. Ciênc Saúde Coletiva. 2019;24(5):1831-44. http:/ / dx.doi.org/ 10.1590/1413-81232018245.14852017

6. França EB, Cunha CC, Vasconcelos AMN, Escalante JJC, Abreu DX, Lima RB, et al. Investigation of illdefined causes of death: assessment of a program's performance in a State from the Northeastern region of Brazil. Rev Bras Epidemiol. 2014;17(1):119-34. http:/ / dx.doi.org/10.1590/1415-790X201400010010ENG

7. França E, Teixeira R, Ishitani L, Duncan BB, CortezEscalante JJ, Morais Neto OL, et al. Ill-defined causes of death in Brazil: a redistribution method based on the investigation of such causes. Rev Saúde Pública. 2014;48(4):671-81. http:/ / dx.doi.org/10.1590/ S0034-8910.2014048005146

8. Frias PG, Szwarcwald CL, Lira PIC. Avaliação dos sistemas de informações sobre nascidos vivos e óbitos no Brasil na década de 2000. Cad Saúde Pública. 2014;30(10):2068-80. http:// dx.doi.org/ 10.1590/0102-311X00196113

9. Brasil. Ministério da Saúde. Estatísticas Vitais DATASUS [Internet]. 2016 [cited 2019 Feb 5]. Available from: http:/ / datasus.saude.gov.br/ informacoes-de-saude/tabnet/estatisticas-vitais

10. Almeida WS, Szwarcwald CL. Adequacy of mortality data and correction of reported deaths from the Proactive Search of Deaths. Ciênc Saúde Coletiva. 2017;22(10):3193-203. http:// dx.doi.org/ 10.1590/1413-812320172210.12002016

11. GBD2015 Mortality and Causes of Death Collaborators. Global, regional, and national life expectancy, all-cause mortality, and cause specific mortality for 249 causes of death, 1980-2015: a systematic analysis for the Global Burden of Disease Study 2015. Lancet. 2016;388:1459-544. http:/ / dx.doi.org/ 10.1016/S0140-6736(16)31012-1

12. Malta DC, Felisbino-Mendes MS, Machado IE, Passos VMA, Abreu DMX, Ishitani LH, et al. Risk factors related to the global burden of disease in Brazil and its Federated Units, 2015. Rev Bras Epidemiol. 2017;20(Suppl 1):217-32. http://dx.doi.org/10.1590/ 1980-5497201700050018

13. GBD 2016 Brazil Collaborators. Burden of disease in Brazil, 1990-2016: a systematic subnational analysis for the Global Burden of Disease Study 2016. Lancet. 2018;392:760-75. http: / dx.doi.org/10.1016/S01406736(18)31221-2

14. Brasil. Ministério da Saúde. Manual de investigação hospitalar nas sessenta cidades selecionadas para óbitos com causa básica classificados como códigos garbage e instrutivo para o preenchimento da ficha de investigação IOCMD-H. Brasília, DF; 2017. Versão 1.0.

15. Naghavi M, Makela S, Foreman K, O’Brien J, Pourmalek F, Lozano R. Algorithms for enhancing public health utility of national causes-of-death data. Popul Health Metr. 2010;8:9. http:/ / dx.doi.org/ 10.1186/1478-7954-8-9

16. Cunha CC, Teixeira R, França E. Assessment of the investigation of ill-defined causes of death in Brazil in 2010. Epidemiol Serv Saúde. 2017;26(1):19-30. http:/ /dx.doi.org/10.5123/s1679-49742017000100003

17. Jorge MHPM, Laurenti R, Gotlieb SLD. O Sistema de Informações sobre Mortalidade-SIM: concepção, implantação e avaliação. In: Brasil. Ministério da Saúde; Organização Pan-Americana de Saúde; Fundação Oswaldo Cruz. A experiência brasileira em sistemas de informação em saúde. Brasília, DF; 2009. p. 71-107.

18. Messias KLM, Bispo Júnior JP, Pegado MFQ, Oliveira LC, Peixoto TG, Sales MAC, et al. The quality of certification of deaths due to external causes in the city of Fortaleza in the State of Ceará, Brazil. Ciênc Saúde Coletiva. 2016;21(4):1255-67. http:/ / dx.doi.org/ 10.1590/1413-81232015214.07922015

19. Matos SG, Proietti FA, Barata RCB. Reliability of cause of death due to violence from information 
systems in Belo Horizonte, Southern Brazil. Rev Saúde Pública. 2007;41(1):76-84. http:/ / dx.doi.org/ 10.1590/S0034-89102007000100011

20. Andrade LT, Diniz AMA. A reorganização espacial dos homicídios no Brasil e a tese da interiorização. Rev Bras Estud Popul. 2013;30(Supl):S171-S191. http:/ / dx.doi.org/10.1590/S0102-30982013000400011

21. Ladeira RM, Malta DC, Morais Neto OL, Montenegro MMS, Soares Filho AM, Vasconcelos CH, et al. Road traffic accidents: Global Burden of Disease study, Brazil and federated units, 1990 and 2015. Rev Bras Epidemiol. 2017;20(Supl 1):157-70. http:/ / dx.doi.org/ 10.1590/1980-5497201700050013

22. Wang H, Dwyer-Lindgren L, Lofgren KT, Rajaratnam JK, Marcus JR, Levin-Rector A, et al. Age-specific and sex-specific mortality in 187 countries, 1970-2010: a systematic analysis for the Global Burden of Disease
Study 2010. Lancet. 2012;380(9859):2071-94. http:/ / dx.doi.org/10.1016/S0140-6736(12)61728-0

Received on: 06/11/2019

Final version presented on: 07/25/2019

Approved on: 08/07/2019

Authors' contribution: Conceição Maria de Oliveira and Denise Leão Ciríaco contributed to the data conception, analysis and interpretation, writing of the article and final approval of the version to be published. Herbert Charles da Silva Barros contributed to data analysis and interpretation, writing of the article and final approval of the version to be published. Cristiana Ferreira da Silva, Carolina Cândida da Cunha and Elisabeth Barboza França contributed to the writing of the article and final approval of the version to be published. 